\title{
ПСИХОЛОГІЧНІ ОСОБЛИВОСТІ ОБРАЗУ Я ВАГІТНИХ
}

\author{
Тетяна Щербак \\ кандидат психологічних наук, доцент, доцент кафедри психології \\ Сумський державний педагогічний університет імені А. С. Макаренка \\ 40002, м. Суми, вул. Роменська 87 \\ shcherbak.tetiana1325@gmail.com, http://orcid.org/0000-0002-7701-9450
}

\section{Анотація}

Статтю присвячено вивченню психологічних особливостей образу Я вагітних, що перебувають на різних термінах вагітності. Образ Я розглянуто як установку особистості щодо себе, складно структуроване та динамічне утворення особистості. В структурі образу Я виділено когнітивний, емоційно-оціночний, поведінковий, соціальноперцептивний аспекти та визначено їх функції. Зазначено, що формування та становлення образу Я відбувається в процесі життя, а під час вагітності значно трансформується, переходячи від образу «Я - вагітна» до образу «Я - мати», а потім - «Я і дитина». Розглянуто психологічний бік змін в ідентичності вагітних. В результаті проведеного дослідження визначено особливості емоційно-оціночного аспекту образу Я вагітних, а саме виявлено наступні особливості: виражене позитивне самоставлення i самовпевненість; середній рівень поваги до себе, аутосимпатії та самоприйняття; більшість вагітних виявили самопослідовність, самоінтерес i низький рівень самообвинувачення. Констатовано високий рівень самооцінки вагітними здоров'я, зовнішності, впевненості у собі; адекватна оцінка розуму, здібностей, характеру та загальна самооцінка. У діапазоні соціально-перцептивного аспекту з'ясовано, що найбільш вираженими є середні показники оцінки ставлення, особистісна ідентичність, емоційно-позитивна форма позначення статі. Констатовано, що для більшості вагітних сексуальна роль та учбово-професійна не є важливими у даний період, натомість велике значення має сімейна приналежність. У рамках когнітивного аспекту виявлено, що серед вагітних переважають жінки 3: емоційно-полярним типом особистості, високим рівнем рефлексії, позитивними ідентифікаційними характеристиками, вираженою сімейною та персональною перспективою. Для більшості досліджуваних найбільше значення мала сфера сім’ї, вагомим для досліджуваних був також фізичний образ. В межах поведінкового аспекту більшості досліджуваних жінок діагностовано здатність сконцентруватись на собі, стриманість, виваженість вчинків, дипломатичність, уміння працювати зі своєю напругою, зберігати емоційну стійкість. Встановлено, що відчуття безпеки, довіри, впевненості, низький рівень тривоги, ворожості та конфліктності властиві більшості досліджуваних.

Ключові слова: образ Я, самосвідомість, самооцінка, самоставлення, ідентичність.

\section{Вступ}

Негативні тенденції в соціально-економічній і демографічній ситуації в Україні, зниження престижу і цінності сім’і, проблема негативного демографічного балансу, патологічної течії вагітності та ускладнень у пологах, як і раніше, залишаються актуальними. Це пов'язано з розвитком демографічних проблем, ростом девіантного материнства, кількістю відмов від дітей тощо. 3 іншого боку, такий інтерес обумовлений 
увагою до проблем особистісного розвитку дорослої людини у зв'язку з іiї новою роллю батька/матері. Дані проблеми гостро поставили питання про необхідність вивчення психологічного стану жінки під час вагітності загалом і психологічних особливостей образу Я вагітних, оскільки останні справляють значний вплив на перебіг вагітності, пологів і майбутні взаємини з дитиною.

Водночас, проблема образу Я майбутніх матерів та особливостей його трансформації під час вагітності залишається недостатньо дослідженою. Наявність суперечностей між потребою оптимізації образу Я вагітних і недостатністю розробленості цієї проблематики визначають актуальність дослідження.

Мета дослідження: вивчити психологічні особливості образу Я вагітних. Для досягнення цієї мети поставлені наступні завдання: 1) підібрати методики дослідження; 2) здійснити емпіричне вивчення психологічних особливостей образу Я майбутніх мам.

\section{Методи дослідження}

Для вирішення поставлених завдань використано наступний комплекс теоретичних та емпіричних методів: теоретичні: аналіз, синтез, узагальнення, класифікація та систематизація сучасних наукових та емпіричних досліджень образу я вагітних, емпіричні методи: 3 використанням методик: 1) методика дослідження самоставлення (МДС) В. В. Століна; 2) методика «Дослідження самооцінки» Т. Дембо, С. Рубінштейн (модиф. А. Прихожан); 3) методика «Хто Я?» (М. Кун, Т. Макпартленд в модифікації Т. В. Румянцевої); 4) проективна методика «Малюнок людини» К. Маховер.

\section{Результати та дискусії}

Образ Я - складноструктурований феномен, головне призначення якого забезпечувати психорегуляцію взаємовідносин між особистістю і довкіллям, потенціалом і спроможностями iï самосвідомості. Він є провідним регулятором поведінки, сприяє досягненню внутрішньої узгодженості особистості. Образ Я містить такі компоненти, як когнітивний, емоційно-оціночний, поведінковий, соціально-перцептивний. Соціальноперцептивний містить показники, які визначають ступінь співмірності з образом Я в уявленні інших, а отже відображає особливості відносин у системі «Я-інший». Когнітивний включає уявлення особистості про саму себе, образ своїх якостей, здібностей, зовнішності, соціальної значимості; емоційно-оціночний передбачає самоповагу i самооцінку; поведінковий - потенційну реакцію поведінки (ті конкретні дії, які можуть бути викликані образом Я).

Під час виношування дитини у жінки відбувається формування таких психологічних новоутворень вагітності, як: образи «Я - вагітна», «Я - мати», «Я і дитина» (Боровикова, 1998; Alpers, 2001). Поетапне становлення образу Я жінки, яка чекає дитину, виступає суттєвою передумовою досягнення нею материнської зрілості (Breen \& McLean, 2010; Paff Ogle, Tyner, \& Schofield-Tomschin, 2013). У процесі вагітності відбуваються значні зміни образу Я майбутньої матері, переоцінка цінностей i життєвих пріоритетів, переорієнтація виконуваних соціальних ролей і взаємовідносин 3 іншими людьми (Афтимичук, 2012; Sieger \& Renk, 2007). Вагітність супроводжується набуттям нової ідентичності та трансформацією іiі особистісної, професійної, сексуальної, гендерної, тілесної та інших ідентичностей. Усвідомлення себе майбутньою матір'ю сприяє становленню материнської ідентичності (Liabsuetrakul, Vittayanont \& Pitanupong, 2007; Васильева, 2008). 
Виходячи 3 теоретичних положень і відповідно до завдань нами було проведено емпіричне дослідження психологічних особливостей образу Я вагітних. Дослідженням було охоплено 40 жінок 18-45 років на різних триместрах вагітності, що знаходяться на медичному обліку по вагітності при жіночій консультації Сумського обласного клінічного перинатального центру.

Емоційно-оціночний аспект образу Я вагітних у дослідженні представлено загальною самооцінкою та загальним самоставленням (табл. 1).

\section{Результати дослідження факторів самоставлення вагітних (за методикою В. В. Століна)}

\begin{tabular}{|c|c|c|}
\hline Фактори самоставлення & Рівень & $\mathbf{N}(\%)$ \\
\hline \multirow{3}{*}{ 1. Інтегральне позитивне самоставлення } & $\mathrm{B}$ & $8(20)$ \\
\hline & $\mathrm{C}$ & $29(72,5)$ \\
\hline & $\mathrm{H}$ & $3(7,5)$ \\
\hline \multirow{3}{*}{ 2. Повага до себе } & $\mathrm{B}$ & $2(5)$ \\
\hline & $\mathrm{C}$ & $24(60)$ \\
\hline & $\mathrm{H}$ & $14(35)$ \\
\hline \multirow{3}{*}{ 3. Аутосимпатія } & $\mathrm{B}$ & $7(17,5)$ \\
\hline & $\mathrm{C}$ & $20(50)$ \\
\hline & $\mathrm{H}$ & $13(32,5)$ \\
\hline \multirow{3}{*}{ 4. Близькість до себе } & $\mathrm{B}$ & $1(2,5)$ \\
\hline & $\mathrm{C}$ & $14(35)$ \\
\hline & $\mathrm{H}$ & $25(62,5)$ \\
\hline \multirow{3}{*}{ 5.Самовпевненість } & $\mathrm{B}$ & $18(45)$ \\
\hline & $\mathrm{C}$ & $14(35)$ \\
\hline & $\mathrm{H}$ & $8(20)$ \\
\hline \multirow{3}{*}{ 6.Самоприйняття } & $\mathrm{B}$ & $2(5)$ \\
\hline & $\mathrm{C}$ & $24(60)$ \\
\hline & $\mathrm{H}$ & $14(35)$ \\
\hline \multirow{3}{*}{ 7.Самопослідовність } & $\mathrm{B}$ & $5(12,5)$ \\
\hline & $\mathrm{C}$ & $22(55)$ \\
\hline & $\mathrm{H}$ & $13(32,5)$ \\
\hline \multirow{3}{*}{ 8.Самозвинувачення } & $\mathrm{B}$ & $3(7,5)$ \\
\hline & $\mathrm{C}$ & $11(27,5)$ \\
\hline & $\mathrm{H}$ & $26(65)$ \\
\hline \multirow{3}{*}{ 9. Самоінтерес } & $\mathrm{B}$ & 0 \\
\hline & $\mathrm{C}$ & $37(92,5)$ \\
\hline & $\mathrm{H}$ & $3(7,5)$ \\
\hline \multirow{3}{*}{ 10. Саморозуміння } & $\mathrm{B}$ & $8(20)$ \\
\hline & $\mathrm{C}$ & $19(47,5)$ \\
\hline & $\mathrm{H}$ & $13(32,5)$ \\
\hline
\end{tabular}

Презентовані дані дають змогу констатувати, що переважній більшості досліджених (72,5\%) властиве інтегральне почуття «за» власне «Я», яке характеризується поліфункціональністю і слугує збереженню внутрішньої стабільності й континуальності «Я», самосприйняттю, самовираженню і самореалізації; 
саморегуляції та контролю, психологічному захисту, інтракомунікації. Високий показник інтегрального позитивного самоставлення мають $20 \%$ жінок. I незначна частка вагітних (7,5\%) вирізняються неприхильністю, відсутністю симпатії та близькості до себе.

Повага до себе у нашому дослідженні постає ще одним аспектом самоставлення. Згідно отриманих даних більшість вагітних (60\%) характеризується емоційним і змістовним об'єднанням віри у свої сили, здібностей, енергії, самостійності, оцінки своїх можливостей контролювати власне життя і бути самопослідовним, розуміти самого себе. Більше третини респондентів (35\%) не поважають себе, відтак мають негативну оцінку своїх можливостей, здібностей, енергії, власної цінності, зневірені у своїх силах.

Середні показники аутосимпатії $\epsilon$ найбільш представленими серед отриманих даних досліджуваних (50\%) респондентів; результати цих вагітних на позитивному полюсі й об’єднують схвалення себе загалом і в суттєвих деталях зокрема, довіру до себе i позитивну самооцінку. Як і за попереднім фактором, більше третини жінок мають низький рівень аутосимпатії, що виражається у перебільшенні власних недоліків, низькій самооцінці, готовності до самозвинувачення. Цим вагітним властиві такі емоційні реакції щодо себе, як роздратування, презирство, глузування, винесення самовироків («так тобі і треба»). Оскільки переважна більшість респондентів $(62,5 \%)$ не $є$ близькими до себе, то ці жінки не виявляють готовність спілкуватися з собою «на рівних» і впевненість в своїй цікавості для інших.

Самовпевненими виявилися 45\% респондентів, які характеризуються вираженим відчуттям сили власного Я, високою сміливістю в спілкуванні, середній рівень уявлень про себе як про самостійну, вольову, енергійну, надійну людину, якій є за що себе поважати належить $35 \%$ досліджуваних. Більшість досліджених жінок (60\%) схарактеризовано як таких, що приймають себе середньою мірою. Високо виражений показник «Самоприйняття» виявлено у 5\% вагітних: вони відповідають дружньому відношенню до себе, схваленню своїх планів і бажань, емоційному і безумовному прийняттю себе такою, якою вона є, навіть із недоліками.

Самопослідовність відображає уявлення про те, що основним джерелом активності і результатів, котрі стосуються як діяльності, так і власної особистості суб'єкта, є він сам. В межах дослідженої нами вибірки більшість вагітних (55\%) чітко переживають власне «Я» як внутрішній стрижень інтегруючий їх особистість і життєдіяльність, ці жінки вважають, що їх доля знаходиться у власних руках. Низький рівень самопослідовності третини респонденток свідчить про віру в підвладність власного Я тимчасовим обставинам, нездатність протистояти долі, погану саморегуляцію, розмитий локус Я, відсутність тенденції шукати причини вчинків і результатів в собі самій.

Більшості жінок вибірки (65\%) не властиве самозвинувачення, яке є індикатором відсутності симпатії і супроводжується негативними емоціями на свою адресу, навіть незважаючи на високу самооцінку якостей і досягнень. Самозацікавленими є 92.5\% респондентів, відтак жінки виявляють інтерес до власної особистості, зокрема, до власних думок і почуттів. Високі показники саморозуміння виявлені у $20 \%$ жінок, середній рівень належить 47,5\% респондентів і низькі показники за даною шкалою у 32,5\% вагітних.

Отже, аналізуючи всі вищезазначені шкали за даною методикою, можемо зробити висновок, що більшість вагітних позитивно ставляться та відчувають симпатію до себе, вирізняються самоповагою, самовпевненістю, є послідовними щодо себе, виявляють інтерес до власної особистості та саморозуміння. Однак, у деяких вагітних виявлено і негативні прояви самоставлення: відстороненість від себе та нерозуміння себе. 
Результати отримані за методикою Т. Дембо, С. Рубінштейн «Дослідження самооцінки» (у модифікації А. Прихожан)» (див. табл. 2) надали інформацію щодо оцінки вагітною свого: 1) здоров'я; 2) розуму, здібностей; 3) характеру; 4) авторитету в оточуючих; 5) вміння багато чого робити своїми руками; 6) зовнішності; 7) впевненості у собі. На базі отриманих кількісних даних можемо засвідчити, що серед значущих і високо оцінених показників вагітні виділяють такі: 1) здоров'я, що вказує на особливу увагу, яку жінки приділяють власному психофізіологічному стану, оскільки останній безпосередньо пов'язаний з успішністю виношування та народження здорової дитини; 2) зовнішність вагомість цього показника для майбутніх мам тісно пов'язана зі змінами у фізичному образі - трансформація обличчя, тіла та зумовлені нею зміни в ході, поведінці й т. ін., також значущості додає соціальний «культ тіла» вагітної, що часто упредметнюється в фотографіях і відеороликах як сімейного, так і загального користування; 3 ) вміння робити щось своїми руками оцінюється високо вагітними, оскільки багато 3 них має більше вільного часу для додаткової самореалізації, з огляду на відпустку по вагітності й пологах.

Таблиияя 2

Рівень самооцінки вагітних (за методикою Т. Дембо, С. Рубінштейн)

\begin{tabular}{|c|c|c|c|c|c|c|c|}
\hline \multirow[b]{2}{*}{$\begin{array}{c}\text { Рівень } \\
\text { самооцінки }\end{array}$} & \multicolumn{7}{|c|}{ Показники, що оцінювались (\%) } \\
\hline & 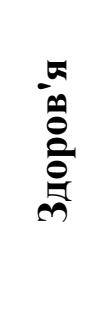 & 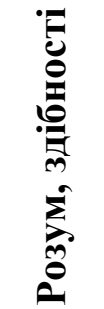 & 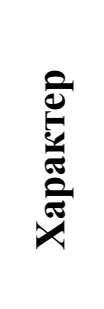 & 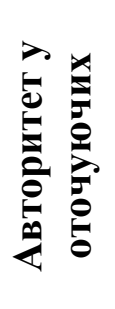 & 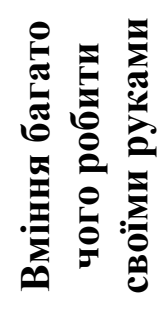 & 鄫 & 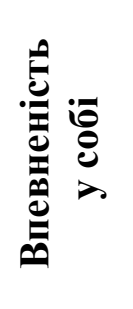 \\
\hline Дуже висока & 17,5 & - & 5 & - & 17,5 & 20 & 7,5 \\
\hline Висока & 45 & 30 & 32,5 & 12,5 & 37,5 & 47,5 & 45 \\
\hline Адекватна & 30 & 62,5 & 50 & 30 & 25 & 27,5 & 32,5 \\
\hline Низька & 7,5 & 7,5 & 12,5 & 57,5 & 20 & 5 & 15 \\
\hline
\end{tabular}

Незначною мірою відрізняються показники рівнів самооцінки, що були отримані за методикою «Хто Я?»: занижена самооцінка спостерігається у 5\% вагітних, адекватну самооцінку мають 65\% опитуваних, нейтральна виявлена у $15 \%$ майбутніх мам. Неадекватно завищена самооцінка простежується у 15\% респондентів, тобто людина відмічає, що вона немає недоліків.

В експерименті соціально-перцептивний аспект вивчався за допомогою шкали «Дзеркальне самоставлення» методики дослідження самоставлення В.В.Століна. Було з'ясовано, що найбільш вираженими є середні та низькі показники оцінки ставлення інших (27,5\% та 67,5\% відповідно), такі жінки вважають, що вони прийняті навколишніми частково або взагалі не прийняті. Ці вагітні не завжди відчувають, що їх люблять інші, цінують за особисті й духовні якості, за здійснювані вчинки і дії, за прихильність груповим нормам і правилам. Найбільш виражений високий показник спостерігається у 5\% жінок, це означає що оцінки оточуючих збігаються з уявленням суб'єкта про свою особистість, характер і діяльність й такі майбутні мами здатні викликати в інших повагу, схвалення та симпатію. Отож, для вагітних характерний низький рівень дзеркального самоставлення, що засвідчує очікування негативних почуттів від узагальненого іншого. 
Додатково було проаналізовано дані, отримані за шкалою аналізу ідентифікаційних характеристик «Соціальне Я» методики «Хто Я?». Пряме позначення статі виявлено у всіх вагітних, що пов’язано із вагомістю реалізації себе як жінки, майбутньої матері а також свідчить, що сфера психосексуальності загалом i порівняння себе 3 іншими представниками такої ж статі приймається особистістю та $\epsilon$ важливою темою самоусвідомлення. Емоційно-позитивна форма позначення статі характерна для 75\% жінок, що $є$ ознакою прийняття своєї привабливості; нейтральне позначення спостерігається у 17,5\% вагітних, що відображає їх рефлексивну позицію; емоційнонегативне позначення виявлено у 7,5 жінок при надії, що вказує на критичне ставлення до статевої ідентичності, внутрішне неблагополуччя. Так само спостерігались і відповіді із непрямим позначенням статі (85\%), через соціальні ролі $(80 \%)$, а саме, дружина, мама та ін., через закінчення позначали стать 100\% майбутніх мам (наприклад, солодка, граційна, кругленька тощо).

Сексуальна роль рідко вказувалась респондентами у відповідях, зокрема, серед опитаних жінок лише 5\% вказували таку роль у відповідях. Це може бути пов'язано із думками майбутніх мам про власну непривабливість, а також із утриманням від інтимних стосунків з чоловіком. Учбово-професійну, соціальну позицію вказали лише 7,5 \% досліджуваних жінок (вчитель, кулінар тощо), що пов'язано із відходженням на другий план основного виду діяльності - навчання або роботи.

Сімейна приналежність вказується у відповідях досліджуваних частіше, що може свідчити про розуміння себе як частини сім’ї, відтак усвідомлюється і приймається сімейна роль. Особливо великий відсоток сімейної приналежності відзначили вагітні жінки (92,5\%). Етнічно-регіональна ідентичність виражає приналежність до нації, країни, держави і т.ін. Таку ідентичність вагітні не позначили, так само, як і світоглядну ідентичність. Групова приналежність виявлена у 22,5\% вагітних жінок, що говорить про зацікавленість у соціальному житті, приналежності до груп, спілок та інших соціальних об'єднань.

Два показники - дружба та спілкування вивчалися нами за допомогою шкали «Комунікативне Я» методики «Хто Я?». За отриманими даними маємо: найвищі показники за шкалою дружба $15 \%$ опитаних і спілкування $12,5 \%$ респондентів, які свідчать про відносну вагомість себе як суб'єкта спілкування. Під час дослідження співвідношення соціальних ролей та індивідуальних характеристик виявлено, що соціальна ідентичність переважає у 17,5\% респондентів, тобто спостерігається високий рівень визначеності схеми «ми-інші» і низький рівень визначеності «я-інші». Особистісна ідентичність домінує у $82,5 \%$ досліджених, тобто високий рівень визначеності схеми «я-інший» і низький рівень визначеності «ми-інші».

Отже, в межах соціально-перцептивного аспекту образу Я вагітні частіше вказують свою стать в емоційно-позитивній формі позначення та сімейну приналежність, однак, при цьому в них виявляється низький рівень дзеркального самоставлення, авторитет у оточуючих i незначущими постають сексуальна, учбово-професійна роль, етнічнорегіональна, світоглядна та групова приналежність.

Когнітивний аспект складають знання власних індивідуальних особливостей. В дослідженні цей аспект вивчався за допомогою шкал методики «Хто Я?»: прояви рефлексії, часові аспекти ідентичності, аналіз сфер життя, аналіз фізичної ідентичності, аналіз психолінгвістичного аспекту ідентичності, валентність ідентичності, оцінка рівня диференційованості ідентичності. 
В ході емпіричного дослідження нами 3'ясовано, що емоційно-полярний тип особистості мають 57,5\% досліджених жінок, тобто для таких вагітних більш властиві емоційні перепади, максималізм в оцінках, виявлення емоцій. Врівноважений тип особистості характерний 37,5\% опитаних, тобто вони володіють більшою стійкістю до стресів, швидше долають конфліктні ситуації, вміють підтримувати конструктивні стосунки з різними людьми, і тими, хто їм в цілому подобається і тими, хто не викликає симпатії. Здатність переносити ситуацію внутрішньої невизначеності є тільки у 5\% респондентів, що може пояснюватись переживанням життєвої кризи або наявністю нерішучості як особистісної риси.

Дослідження проявів рефлексії засвідчує, що більшість вагітних (85\%) схильні усвідомлювати внутрішні психічні стани, знати, розуміти себе. Вивчення часових аспектів ідентичності вказує, що часова інтегрованість опитуваних знаходиться на середньому рівні. Перспективна ідентичність або перспективне «Я» виявлено у 20\% досліджуваних, тобто в самоописах жінки вказували ідентифікаційні характеристики, що пов'язані 3 перспективами, мріями, які стосуються різних галузей життя. У всіх респондентів переважна більшість дієслів теперішньої форми демонструє активність і усвідомленість дій людини. Розширення і збагачення образу Я у процесі особистісного розвитку тісно пов'язано з рефлексією власних емоційних переживань і тілесних відчуттів. 3 настанням вагітності багато жінок відзначають зміни самопочуття, що виражаються в дратівливості, слізливості, підвищеній втомлюваності, зміні апетиту, нудоті, зниженні лібідо, сонливості протягом дня. Свою фізичну ідентичність позначили 70\% жінок, серед них суб'єктивне описання своїх фізичних даних, зовнішності містили 32,5\% відповідей; фактичний опис своїх фізичних даних, опис зовнішності, проявів хвороби, місця розташування характерний для 22,5\% відповідей; пристрасті в їжі і шкідливі звички не було описано жодною з учасниць дослідження.

В ході аналізу сфер життя досліджуваних з'ясовано, що найбільше значення для них має сфера сім’ї (90\%), цей факт пояснюється збільшенням цінності сім’ї у період виношування дитини, а у жінок третього триместру вагітності також це пов'язано 3 перебуванням у відпустці (див. рис. 1).

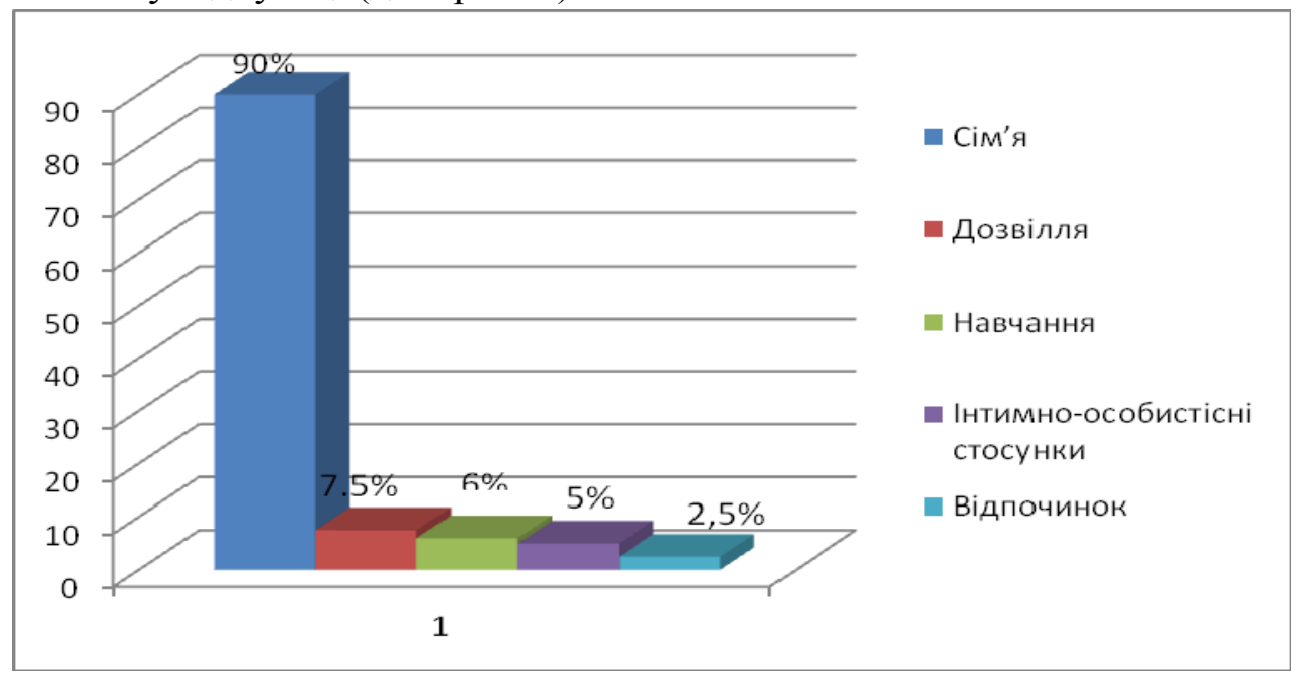

Рис. 1. Особливості представленості сфер життя вагітних

Аналіз психолінгвістичного аспекту ідентичності дає змогу констатувати, що: у всіх респондентів недостатня впевненість у собі, вони недооцінюють своєї ефективності. У більшості жінок (45\%) переважає демонстративність й емоційність. У деяких респондентів слабка диференційованість ідентичності. 45\% вагітних мають потребу у 
визначеності. У ході вивчення валентності ідентичності досліджуваних з'ясовано, що переважаючий емоційно-оціночний тон ідентифікаційних характеристик у самоописах досліджуваних визначає різноманітні види валентності ідентичності, у більшості опитаних $(65 \%)$ вони позитивна - позитивні ідентифікаційні характеристики переважають над негативними (щаслива, добрий, розумна тощо). Негативної валентності ідентичності виявлено не було. Отож, види валентності ідентичності відповідають видам самооцінки ідентичності.

Переважна більшість досліджуваних жінок (62,5\%) характеризуються високим рівнем диференційованості ідентичності, відтак більшість вагітних комунікабельні, впевнені у собі, мають високий рівень соціальної компетенції і самоконтролю. Дослідження «Перспективного Я» вказує на перевагу сімейної (60\%) та персональної перспективи, тобто їх наміри та прагнення пов'язані з сім'єю, інтересами, захопленнями, конкретними заняттями і досягненням певних результатів також з персональними особливостями, поведінкою $(32,5 \%)$.

За методикою «Намалюй людину» К. Маховер було виявлено, що у 87,5\% вагітних на малюнку наявний образ дитини, що може вказувати на його спорідненість з образом себе вагітної; у 85\% наявні додаткові ознаки жіночності.

Поведінковий аспект формується під дією трьох попередніх аспектів і виявляється в потенційній поведінковій реакції (тих конкретних діях, які можуть бути викликані образом Я). В емпіричному дослідженні цей аспект вивчався за допомогою шкали «Діяльне Я» методики «Хто Я?». Отримані результати дають підстави для висновків, що більшості досліджуваних жінок (90\%) характерна здатність сконцентруватись на собі, стриманість, виваженість вчинків, дипломатичність, уміння працювати зі своєю напругою, тривогою, зберігати емоційну стійкість, тобто їх Діяльне Я, а відтак і поведінковий аспект образу Я є віддзеркаленням сукупності емоційно-вольових і комунікативних здібностей, особливостей взаємодії. Найменше Діяльне Я виражене у 10\% вагітних.

Також поведінковий аспект досліджувався нами за допомогою методики «Намалюй людину», а саме показників таких симптомокомплексів, як незахищеність, тривожність, депресивність, ворожість, конфліктність, труднощі спілкування. Встановлено, що відчуття безпеки, довіри, впевненості властиве 77,5\% обстежуваних, середній рівень почуття незахищеності мають 15\% осіб, 7,5\% вагітних відзначаються високим рівнем почуття незахищеності, тобто відчувають недостатність захисних сил, на які можна покластися; високий рівень схильності до переживання тривоги властивий 7,5\% обстежуваних, середній характерний для 15\%, відповідно низький - наявний у 77,5\% жінок (див. рис. 2).

Відтак, частка вагітних, яким властиві негативні прояви поведінкового аспекту образу Я $\epsilon$ незначною і може пояснюватись побоюваннями жінок щодо зміни свого статусу, звичного укладу життя та взаємодії з членами родини. Аналіз матеріалів дослідження, які були отримані у процесі вивчення симптомокомплексу «ворожість», вказує, що переважна більшість обстежуваних (80\%) мають низький рівень тривожності, середній рівень вияву ворожих намірів щодо себе та навколишніх мають $15 \%$ вагітних і високий - 5\% учасників дослідження, тобто виявляють емоційно-особистісне негативне ставлення до інших суб'єктів або об'єктів та є схильними до конфліктної поведінки.

За симптомокомплексом «конфліктність» більшість досліджуваних (77,5\%) не виявляють конфліктних способів поведінки, установок щодо себе або оточуючих, середній рівень конфліктності властивий для 17,5\% осіб, а високий - для 5\%, тобто в умовах протистояння мотивів, прагнень, інтересів, поглядів цих осіб 3 іншими їх поведінка характеризується протиборством. 


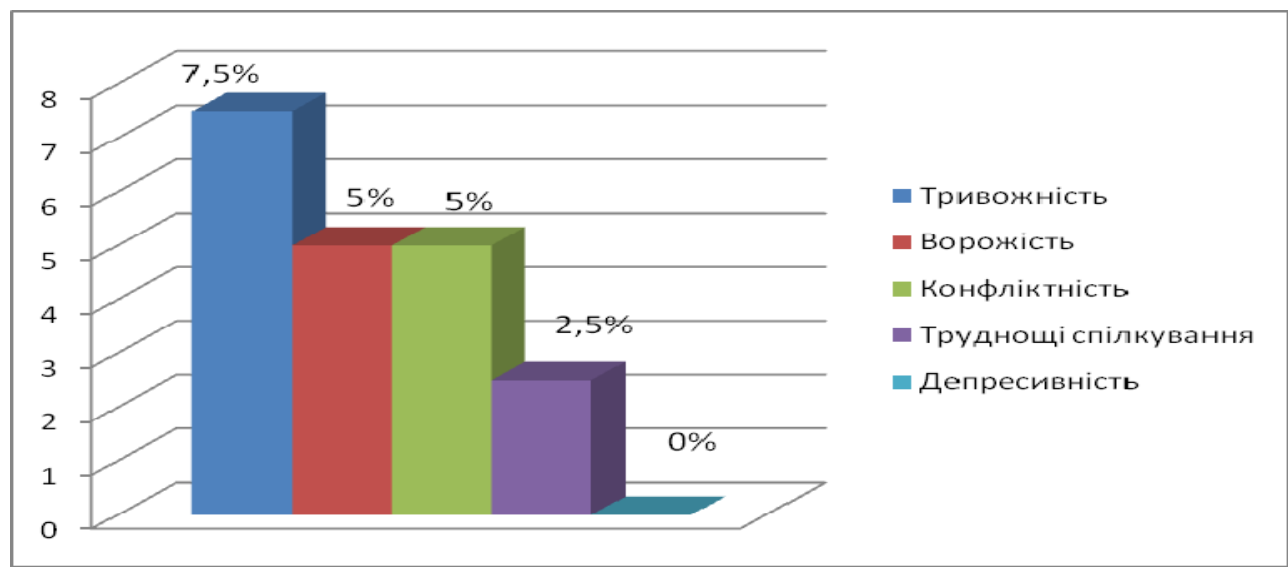

\section{Рис. 2. Прояв основних симптомокомплексів поведінкового аспекту образу Я вагітних}

За показником «труднощі спілкування» найбільший відсоток $(82,5 \%)$ респондентів не відчувають утруднень у процесі комунікації, 15\% - виявляють середній ступінь прояву труднощів у сфері комунікації, високий рівень показника i, відповідно, найбільші труднощі у спілкуванні є характерними лише для 2,5\% вагітних, такі особи виявляють неприйняття іншої людини, відсутність інтересу до неї, замкнутість, внутрішню скутість, нестриманість, негнучкість рольової поведінки, невміння точно й зрозуміло висловити свої думки, труднощі у поясненні, невміння вести обговорення. Також констатуємо, що показники високого рівня депресивності у групі обстежуваних відсутні, середній рівень вияву даного симптомокомплексу наявний у 2,5\% учасників дослідження, а переважна більшість (97,5\%) взагалі не мають ознак депресивності.

Розглянувши первинні результати дослідження, нами отримано загальне уявлення про особливості образу Я, змістовне наповнення його структурних аспектів. Наступний рівень порівняльного аналізу був пов'язаний із застосуванням параметричного критерія коефіцієнт Спірмена, що дозволив виявити прямі зв'язки між основними показниками у вищезазначених методиках.

Кореляційним аналізом встановлено наявність таких тісних зв'язків у вагітних:

1) між інтегральним показником самоставлення та: а) самооцінкою розуму $\left(\mathrm{r}=0,386^{*}\right)$ (при $\left.\mathrm{p} \leq 0,05\right)$; б) самооцінкою характеру $\left(\mathrm{r}=0,351^{*}\right)$ (при $\left.\mathrm{p} \leq 0,05\right)$; в) самооцінкою авторитету $\left(\mathrm{r}=0,381^{*}\right)$ (при $\left.\mathrm{p} \leq 0,05\right)$; г) самооцінкою впевненості $\left(\mathrm{r}=0,501^{* *}\right)$ (при $\left.\mathrm{p} \leq 0,01\right)$. Відповідно, за умови оцінки себе вагітною як розумної, авторитетної, самовпевненої та 3 гарним характером високим буде і показник самоставлення, переважатиме інтегральне почуття «за» власне «Я», яке слугує для самосприйняття, самовираження та самореалізаціі; збереження внутрішньої стабільності та континуальності «Я», саморегуляції та контролю, психологічного захисту, інтракомунікації;

2) вагітні, що оцінюють себе як розумних $\left(\mathrm{r}=0,572^{* *}\right.$ ) (при $\left.\mathrm{p} \leq 0,01\right)$ та впевнених $\left(\mathrm{r}=0,320^{*}\right)$ (при $\left.\mathrm{p} \leq 0,05\right)$ поважають себе значимо частіше;

3) аутосимпатія значимо частіше виявляється у тих майбутніх мам, які оцінюють свої вміння $\left(\mathrm{r}=0,329^{*}\right)$ (при $\left.\mathrm{p} \leq 0,05\right)$, здоров'я $\left(\mathrm{r}=0,333^{*}\right)$ (при $\left.\mathrm{p} \leq 0,05\right)$, характер $\left(\mathrm{r}=0,406^{* *}\right)$ (при $\mathrm{p} \leq 0,01)$ та авторитет серед інших ( $\mathrm{r}=0,380^{*}$ ) (при $\left.\mathrm{p} \leq 0,05\right)$ на високому рівні;

4) рівень тривожності вагітної зростатиме за умови погіршення ставлення інших, про що свідчить обернений взаємозв'язок між цими показниками $\left(\mathrm{r}=-0,321^{*}\right)$ (при $\left.\mathrm{p} \leq 0,05\right)$;

5) впевнені жінки частіше виявляють близькість до себе, готовність спілкуватися 3 собою «на рівних», впевненість в своїй цікавості для інших $\left(\mathrm{r}=0,317^{*}\right)$ (при $\left.\mathrm{p} \leq 0,05\right)$; 
самовпевнені вагітні вирізняються високими самооцінками показників «розум» $\left(\mathrm{r}=0,729^{* *}\right)$ (при $\mathrm{p} \leq 0,01)$ i «характер» $\left(\mathrm{r}=0,399^{*}\right)$ (при $\left.\mathrm{p} \leq 0,05\right)$; більш позитивне самосприйняття мають впевнені у собі майбутні мами $\left(\mathrm{r}=0,317^{*}\right)$ (при $\left.\mathrm{p} \leq 0,05\right)$;

6) високу самопослідовність виявляють досліджувані, які високо оцінюють свої розумові здібності $\left(\mathrm{r}=0,517^{* *}\right.$ ) (при $\left.\mathrm{p} \leq 0,01\right)$, такі вагітні чітко переживають власне «Я» як внутрішній стрижень інтегруючий їх особистість і життєдіяльність;

7) особливий інтерес до себе виявляють впевнені у собі $\left(\mathrm{r}=0,333^{*}\right)$ (при $\left.\mathrm{p} \leq 0,05\right)$ та своєму авторитеті серед інших $\left(\mathrm{r}=0,342^{*}\right)$ (при $\left.\mathrm{p} \leq 0,05\right)$ вагітні.

Наступним рівнем порівняльного аналізу стало виявлення вікових відмінностей в образі Я та відмінностей в системі уявлень про себе у групах жінок із різним терміном вагітності. Статистичний аналіз не виявив достовірних відмінностей між вагітними різних вікових категорій, як не виявлено відмінностей і між групами вагітних 1 і 2 триместрів та 2 і 3 триместрів, натомість вони знайдені між жінками, які знаходяться на 1 і 3 триместрі вагітності. Так, відмінності виявились у рівні саморозуміння, близькості до себе, незахищеності та тривожності (див. табл. 3).

Таблиия 3

\section{Відмінності у факторах самоставлення у жінок на I і III триместрі вагітності}

\begin{tabular}{|c|c|c|c|c|c|c|}
\hline \multicolumn{7}{|c|}{ Саморозуміння } \\
\hline \multirow{3}{*}{ Рівень показника } & \multicolumn{4}{|c|}{ Триместр вагітності } & \multirow{2}{*}{\multicolumn{2}{|c|}{ Критерії та їх значимість }} \\
\hline & \multicolumn{2}{|c|}{ Перший } & \multicolumn{2}{|c|}{ Третій } & & \\
\hline & $\mathrm{N}$ & $\%$ & $\mathrm{~N}$ & $\%$ & $\chi^{2}$ & $\mathrm{p}$ \\
\hline Низький & 13 & 32,5 & 10 & 25 & \multirow{3}{*}{2,285} & \multirow{3}{*}{$<0,05$} \\
\hline Середній & 19 & 47,5 & 16 & 40 & & \\
\hline Високий & 8 & 20 & 14 & 35 & & \\
\hline \multicolumn{7}{|c|}{ Близькість до себе } \\
\hline \multirow{3}{*}{ Рівень показника } & \multicolumn{4}{|c|}{ Триместр вагітності } & \multirow{2}{*}{\multicolumn{2}{|c|}{ Критерії та їх значимість }} \\
\hline & \multicolumn{2}{|c|}{ Перший } & \multicolumn{2}{|c|}{ Третій } & & \\
\hline & $\mathrm{N}$ & $\%$ & $\mathrm{~N}$ & $\%$ & $\chi^{2}$ & $\mathrm{p}$ \\
\hline Низький & 25 & 62,5 & 18 & 45 & \multirow{3}{*}{3,439} & \multirow{3}{*}{$<0,05$} \\
\hline Середній & 14 & 35 & 18 & 45 & & \\
\hline Високий & 1 & 2,5 & 4 & 10 & & \\
\hline \multicolumn{7}{|c|}{ Незахищеність } \\
\hline \multirow{3}{*}{ Рівень показника } & \multicolumn{4}{|c|}{ Триместр вагітності } & \multirow{2}{*}{\multicolumn{2}{|c|}{ Критерії та їх значимість }} \\
\hline & \multicolumn{2}{|c|}{ Перший } & \multicolumn{2}{|c|}{ Третій } & & \\
\hline & $\mathrm{N}$ & $\%$ & $\mathrm{~N}$ & $\%$ & $\chi^{2}$ & $\mathrm{p}$ \\
\hline Низький & 27 & 67,5 & 31 & 77,5 & \multirow{3}{*}{1,018} & \multirow{3}{*}{$<0,05$} \\
\hline Середній & 9 & 22,5 & 6 & 15 & & \\
\hline Високий & 4 & 10 & 3 & 7,5 & & \\
\hline \multicolumn{7}{|c|}{ Тривожність } \\
\hline \multirow{3}{*}{ Рівень показника } & \multicolumn{4}{|c|}{ Триместр вагітності } & \multirow{2}{*}{\multicolumn{2}{|c|}{ Критерії та їх значимість }} \\
\hline & \multicolumn{2}{|c|}{ Перший } & \multicolumn{2}{|c|}{ Третій } & & \\
\hline & $\mathrm{N}$ & $\%$ & $\mathrm{~N}$ & $\%$ & $\chi^{2}$ & $\mathrm{p}$ \\
\hline Низький & 25 & 62,5 & 28 & 70 & \multirow{3}{*}{0,512} & \multirow{3}{*}{$<0,05$} \\
\hline Середній & 11 & 27,5 & 9 & 22,5 & & \\
\hline Високий & 4 & 10 & 3 & 7,5 & & \\
\hline
\end{tabular}

Примітка: жирним шрифтом відзначені достовірні розходження на рівні $\mathrm{p}<0,05$.

Отже, наприкінці вагітності у жінок збільшується міра близькості до самих себе, готовність спілкуватися 3 собою «на рівних», впевненість в своїй цікавості для інших і 
вміння розуміти себе. Однак, одночасно, у незначної кількості досліджених вагітних виявляються i негативні симптомокомплекси, такі як підвищена тривожність i незахищеність. Змістовно близькі до отриманих нами результати дослідження, згідно 3 якими вагітність і материнство, пов'язані з проявом фізичних аспектів жіночності, прийняттям своєї тілесності (Kamysheva, Skouteris, Wertheim, Paxton \& Milgrom, 2008; Белогай, 2013). В образі тіла відображається смислова наповненість, яка виявляється у підвищеній увазі до частин тіла, що відповідають за опору та жіночу ідентичність.

Ще один аспект нашого дослідження, що вказує на незначущість сексуальної ролі для вагітних, підтверджують результати, згідно з якими у вагітних жінок збільшується дистанція в спілкуванні з чоловіком через фізіологічні зміни, що відбуваються з вагітною жінкою і неможливість повноцінного сексуального життя (McLean \& Thorne, 2008).

За даними дослідження О. Афтимичук, трансформації у соціальному Я вагітної, перш за все, обумовлені змінами в соціальній ідентичності жінки. Етап рольової ідентифікації передбачає: ідентифікацію з новою рольовою позицією (Афтимичук, 2012). Водночас автор поза увагою залишає факт впливу на соціальний аспект образу Я рівня дзеркального самоставлення. Нами ж було з'ясовано, що для вагітних характерним є низький рівень дзеркального самоставлення та оцінка власного авторитету у оточуючих. Це питання залишимо для подальшого детального вивчення.

\section{Висновки}

Під час виношування дитини у сфері самосвідомості майбутньої матері відбуваються істотні зміни в системі уявлень про себе. Відбувається трансформація у структурі образу Я, як в сталих аспектах - ядрі, так і в змінних інваріантах - периферії образу Я. Визначаючим фактором формування образу Я майбутньої матері $є$ перехід психологічного синдрому вагітності з підсвідомого рівня на рівень усвідомлення. Образ Я вагітних жінок має більшу когнітивну ускладненість і більшу диференційованість уявлень про себе, характеризується актуалізацією сімейних стосунків, стану здоров'я, очікування позитивного ставлення від інших.

В рамках емпіричного дослідження психологічних особливостей образу Я виявлено, що для емоційно-оціночного аспекту вагітних характерні: інтегральне позитивне самоставлення, самоповага, аутосимпатія, самовпевненість, самоприйняття, самопослідовність. Однак, у вагітних жінок виявлено і негативні прояви самоставлення: відстороненість від себе та виражені середній і низький рівні самоінтересу. Серед значущих і високо оцінених показників вагітні виділяють такі: 1) здоров'я, що вказує на особливу увагу, яку жінки надають власному психофізіологічному стану і зовнішності. Незначущими є сексуальна, учбово-професійна роль, етнічно-регіональна, світоглядна та групова приналежність. Для позначення статі використовується емоційно-позитивна форма, що пов'язано із вагомістю реалізації себе як жінки, майбутньої матері. Найбільше значення для вагітних має сфера сім'ї.

В когнітивному аспекті образу Я досліджувані характеризуються переважаючою над соціальною особистісною ідентичністю; позитивними ідентифікаційними характеристиками; високим рівнем диференційованості ідентичності та рефлексії. Поведінковий аспект образу Я характеризується наявністю вираженого відчуття безпеки, довіри; здатністю сконцентруватись на собі, стриманістю. Для вагітних характерний середній рівень конфліктності, незахищеності та тривожності; відсутність труднощів у спілкуванні та депресивності. Достовірні статистичні відмінності між аспектами образу Я 
жінок, які знаходяться на 1 і 3 триместрі вагітності свідчать про трансформацію таких аспектів системи уявлень про себе, як: близькість до себе, саморозуміння, а також підвищення рівня тривожності та незахищеності.

Проведене дослідження не вичерпує всіх аспектів проблеми образу Я вагітних, тому ми вбачаємо перспективу подальших науково-психологічних досліджень у вивченні чинників, що впливають на трансформацію системи уявлень про себе у майбутніх матерів.

\section{Література}

1. Афтимичук, О.Е. (2012). Предпосылки становления социальной идентичности личности беременной женщины в условиях фитнеса. Здоровье для всех, 2, 21-27. Режим доступа : http://ojs.polessu.by/ZdV/article/view/414

2. Белогай, К.Н. (2013). Телесность женщины в связи с реализацией репродуктивной функции. Вестник Кемеровского государственного университета, 2-1, 137-142. Режим доступа : https://vestnik.kemsu.ru/jour/article/view/86/0

3. Боровикова, Н.В. (1998). Психологические аспекты трансформации Я-концепции беременной женщины. Тезисы конферениии «Перенатальная психология и нервнопсихическое развитие детей» (2. Санкт-Петербург, 27 мая 1998 г.) (с.7-8). СанктПетербург : СПб ун-т.

4. Васильева, Е.В. (2008). Особенности социальной идентичности беременных женщин с различным материнским отношением к детям. Известия Самарского научного иентра Российской академии наук. Выпуск «Педагогика и психология», "Филология и искусствоведение», 1, 134-141. Режим доступа : http://www.ssc.smr.ru/izv 2008 6.html

5. Тихонович, О.В. (2008). Исследование Я-образа: методологические и методические проблемы. Психологический журнал, 1(17), 73-77. Режим доступа : http://elibrary.miu.by/journals!/item.pj/issue.17/article.12.phtml

6. Alpers, R. (2001). The changing self-concept of pregnant and parenting teens. Journal of Professional Nursing, 14(2), 111-118. https://doi.org/10.1016/s8755-7223(98)80039-2

7. Breen, A.V., \& McLean, K.C. (2010). Constructing resilience: Adolescent motherhood and the process of self-transformation. In K.C. McLean \& M. Pasupathi (Eds.), Advancing responsible adolescent development. Narrative development in adolescence: Creating the storied self (pp. 151-168). New York : Springer Science, Business Media. https://doi.org/10.1007/978-0-387-89825-4 8

8. Kamysheva, E., Skouteris, H., Wertheim, E.H, Paxton, S.J., \& Milgrom, J. (2008). Examination of a multi-factorial model of body-related experiences during pregnancy: the relationship among physical symptoms, sleep quality, depression, self-esteem, and negative body attitudes. Body Image, 5(2), 152-163. https://doi.org/10.1016/j.bodyim.2007.12.005

9. Liabsuetrakul, T., Vittayanont, A., \& Pitanupong, J. (2007). Clinical applications of anxiety, social support, stressors, and self-esteem meaured during pregnancy and postpartum for screening postpartum depression in Thai women. Journal of Obstetrics and Gynaecology Research, 33(3), 333-340. https://doi.org/10.1111/i.1447-0756.2007.00532.x

10. Macola, L., Nogueira, I., \& Carmona, E. (2010). Assessment of self-esteem in pregnant women using Rosenberg's self-esteem. Revista da Escola de Enfermagem da USP, 44(3), 570-577. https://doi.org/10.1590/s0080-62342010000300004

11. McLean, K.C., \& Thorne, A. (2006). Identity light: Entertainment stories as a vehicle for self-development. In D.P. McAdams, R. Josselson, \& A. Lieblich (Eds.), Identity and Story: Creating Self in Narrative (pp. 111-127). American Psychological Association. https://psycnet.apa.org/doi/10.1037/11414-005

12. Paff Ogle, J., Tyner, K., \& Schofield-Tomschin, S. (2013). The role of maternity dress consumption in shaping the self and identity during the liminal transition of pregnancy. Journal of Consumer Culture, 13(2), 119-139. doi: 10.1177/1469540513480161

13. Sieger, K., \& Renk, K. (2007). Pregnant and parenting adolescents: A study of ethnic identity, emotional and behavioral functioning, child characteristics, and social support. Journal of Youth and Adolescence, 36(4), 567-581. https://psycnet.apa.org/doi/10.1007/s10964-007-9182-6 
14. Skouteris, H., Carr, R., Wertheim, E.H, Paxton, S.J., \& Duncombe, D.A. (2005). A prospective study of factors that lead to body dissatisfaction during pregnancy. Body Image, 2(4), 347-361. https://doi.org/10.1016/j.bodyim.2005.09.002

\section{References}

1. Aftimichuk, O.E. (2012). Predposylki stanovlenija social'noj identichnosti lichnosti beremennoj zhenshhiny $\mathrm{v}$ uslovijah fitnesa [Background of the formation of social identity of a pregnant woman in fitness conditions]. Zdorov'e dlja vseh - Health for all, 2, 21-27. Retrieved from http://ojs.polessu.by/ZdV/article/view/414 [in Russian].

2. Belogai, K.N. (2013). Telesnost' zhenshhiny v sviazi s realizaciei reproduktivnoi funkcii. [Female corporality in connection with reproductive function]. Vestnik Kemerovskogo gosudarstvennogo universiteta - Bulletin of Kemerovo State University, 2-1, 137-142. Retrieved from https://vestnik.kemsu.ru/jour/article/view/86/0 [in Russian].

3. Borovikova, N.V. (1998). Psihologicheskie aspekty transformacii Ja-koncepcii beremennoj zhenshhiny [Psychological aspects of the transformation of the self-concept of a pregnant woman]. Proceedings from PPNRD '98: Konferencija «Perenatal'naja psihologija i nervnopsihicheskoe razvitie detej» - Conference "Transnational Psychology and Neuropsychic Development of Children» (Saint Petersburg, 27-th, may 1998) (pp. 7-8). Saint Petersburg : Saint Petersburg University [in Russian†.

4. Vasil'eva, E.V. (2008). Osobennosti social'noi identichnosti beremennyh zhenshhin s razlichnym materinskim otnosheniem $\mathrm{k}$ detiam [Features of the social identity of pregnant women with different maternal attitudes towards children]. Izvestija Samarskogo nauchnogo centra Rossijskoi akademii nauk. Vypusk «Pedagogika $i$ psihologija», "Filologija $i$ iskusstvovedenie» - Bulletin of the Samara Scientific Center of the Russian Academy of Sciences. Issue "Pedagogy and Psychology», "Philology and Art History», 1, 134-141. Retrieved from http://www.ssc.smr.ru/izv 2008 6.html 「in Russian].

5. Tihonovich, O.V. (2008). Issledovanie Ja-obraza: metodologicheskie i metodicheskie problemy [Research of the self-image: methodological and methodological problems]. Psihologicheskij zhurnal - Psychological Journal, 1(17), 73-77. Retrieved from http://elibrary.miu.by/journals!/item.pi/issue.17/article.12.phtml [in Russian].

6. Alpers, R. (2001). The changing self-concept of pregnant and parenting teens. Journal of Professional Nursing, 14(2), 111-118. https://doi.org/10.1016/s8755-7223(98)80039-2

7. Breen, A.V., \& McLean, K.C. (2010). Constructing resilience: Adolescent motherhood and the process of self-transformation. In K.C. McLean \& M. Pasupathi (Eds.), Advancing responsible adolescent development. Narrative development in adolescence: Creating the storied self (pp. 151-168). New York : Springer Science, Business Media. https://doi.org/10.1007/978-0-387-89825-4_8

8. Kamysheva, E., Skouteris, H., Wertheim, E.H, Paxton, S.J., \& Milgrom, J. (2008). Examination of a multi-factorial model of body-related experiences during pregnancy: the relationship among physical symptoms, sleep quality, depression, self-esteem, and negative body attitudes. Body Image, 5(2), 152-163. https://doi.org/10.1016/j.bodyim.2007.12.005

9. Liabsuetrakul, T., Vittayanont, A., \& Pitanupong, J. (2007). Clinical applications of anxiety, social support, stressors, and self-esteem meaured during pregnancy and postpartum for screening postpartum depression in Thai women. Journal of Obstetrics and Gynaecology Research, 33(3), 333-340. https://doi.org/10.1111/i.1447-0756.2007.00532.x

10. Macola, L., Nogueira, I., \& Carmona, E. (2010). Assessment of self-esteem in pregnant women using Rosenberg's self-esteem. Revista da Escola de Enfermagem da USP, 44(3), 570-577. https://doi.org/10.1590/s0080-62342010000300004

11. McLean, K.C., \& Thorne, A. (2006). Identity light: Entertainment stories as a vehicle for self-development. In D.P. McAdams, R. Josselson, \& A. Lieblich (Eds.), Identity and Story: Creating Self in Narrative (pp. 111-127). American Psychological Association. https://psycnet.apa.org/doi/10.1037/11414-005

12. Paff Ogle, J., Tyner, K., \& Schofield-Tomschin, S. (2013). The role of maternity dress consumption in shaping the self and identity during the liminal transition of pregnancy. Journal of Consumer Culture, 13(2), 119-139. doi: 10.1177/1469540513480161 
13. Sieger, K., \& Renk, K. (2007). Pregnant and parenting adolescents: A study of ethnic identity, emotional and behavioral functioning, child characteristics, and social support. Journal of Youth and Adolescence, 36(4), 567-581. https://psycnet.apa.org/doi/10.1007/s10964-007-9182-6

14. Skouteris, H., Carr, R., Wertheim, E.H, Paxton, S.J., \& Duncombe, D.A. (2005). A prospective study of factors that lead to body dissatisfaction during pregnancy. Body Image, 2(4), 347-361. https://doi.org/10.1016/j.bodyim.2005.09.002

\author{
PSYCHOLOGICAL FEATURES OF THE SELF-IMAGE OF THE PREGNANT \\ Tetiana Shcherbak \\ PhD in Psychology, Associate Professor, \\ Associate Professor of the Department of Psychology \\ Sumy State Pedagogical University named after A. S. Makarenko \\ 87, Romenska Str., Sumy, Ukraine, 40002 \\ shcherbak.tetiana1325@gmail.com, http://orcid.org/0000-0002-7701-9450
}

\begin{abstract}
The article is devoted to the study of psychological peculiarities of the self-image of pregnant women who are on different terms of pregnancy. Self-image has been considered as a personal setting for oneself, a complex structured and dynamic personality formation. Cognitive, emotional-evaluative, behavioral, social-perceptual aspects have been defined in the structure of self-image, and their functions have been installed. It has been indicated that the formation of self-image takes place during the life. During pregnancy it is transformed significantly from the image «I am pregnant» to the image «I am a mother» and then - «The child and I». The psychological side of changes of pregnant women identity has been considered. As a result of the research, the peculiarities of the emotional-evaluative aspect of the self-image of pregnant women have been identified. The following features have been revealed: expressed positive selfesteem and self-confidence; average level of self-esteem, auto sympathy and self-acceptance; most pregnant women showed self-consistency, self-interest, and low levels of self-blame. A high level of self-esteem of pregnant women's health, physical appearance, and self-confidence, adequate assessment of reason, ability, character and overall self-esteem have been ascertained. In the range of social-perceptual aspect, it has been found that the most pronounced characteristics are the middle and low rates of attitude assessment, personal identity, and emotionally-positive form of gender designation. It has been stated that for most pregnant women, sexual role, educational and professional roles are not important at this time, but family affiliation is of a great importance. Within the cognitive aspect, it has been found that women with an emotionally polar personality type, a high level of reflection, positive identification characteristics, a pronounced family and personal perspective predominated among pregnant women. Family sphere and the physical image have been of the greatest importance for the most respondents. Within the behavioral aspect of all respondents, the ability to concentrate on oneself, restraint, prudence, diplomacy, the ability to work with one's tension, and maintain emotional stability have been diagnosed. Feeling of security, confidence, low levels of anxiety, hostility and conflict of most subjects have been found.
\end{abstract}

Keywords: self image, self-consciousness, self-esteem, self-alignment, identity.

Подано 10.02.2020

Рекомендовано до друку 19.02.2020 